Creative

\title{
Death House Desiderata: A Hunger for Justice, Unsated
}

Robert Johnson ${ }^{1, *}$, Alexa Marie Kelly ${ }^{1}$, Sarah Bousquet ${ }^{1}$, Susan Nagelson ${ }^{2}$ and Carla Mavaddat ${ }^{3}$

1 Department of Justice, Law and Criminology, American University, 4400 Massachusetts Avenue, Washington, DC 20016, USA; E-Mails: ak2534a@american.edu (A.M.K.); sb2259a@american.edu (S.B.)

2 New England College, 98 Bridge St, Henniker, NH 03242, USA; E-Mail: nagelsen@gmail.com

3 McGill University, 845 Rue Sherbrooke Ouest, Montreal, QC H3A 0G4, Canada; E-Mail: cmavaddat@gmail.com

* Author to whom correspondence should be addressed; E-Mail: robert.johnson@american.edu; Tel.: +1-202-885-2951.

Received: 30 March 2014; in revised form: 22 April 2014 / Accepted: 23 April 2014 /

Published: 25 April 2014

\begin{abstract}
The death penalty lives on in America, with some 1350 prisoners put to death since 1976, when the modern American death penalty was reborn. Most prisoners get a last meal of their choice, though that choice is constrained by cost and, often, the stock in the prison kitchen. Last meals can be thought of as brief moments of autonomy in a relentlessly dehumanizing execution process. They also entail a distinctive cruelty. At their lowest point, prisoners seek comfort food but are never comforted. This meal is no entre to a relationship, but instead a recipe for abandonment. Dignity is nowhere to be found on the death house menu. Yet hope lingers, even here; human beings, it seems, cannot live or die without hope. Justice, the most profound human hunger, goes unsated by design.
\end{abstract}

Keywords: last meals; death house; executions; photography 


\section{Death House Serenade}

\section{By Robert Johnson}

A burnished brown river ripples and rises and falls into

Cracks like craters on the light side of a cavernous full moon

Made from the best damn batter this side of the prison wall

Golden eyes, yellow on white, shifting slightly, smile up at me,

Stars in a sweet, soothing, sensual serenade staged

\section{Atop a plain paper tableau}

A few plastic props in tow, all

Framed by a flickering fluorescent light

The gurney out of sight

Obscured in shadows;

$-$

Pancakes \& Eggs

Round \& Profound

The circle of life

Life come full circle

Hot syrup, cold mass

Sweet and sour

A delicious dialectic

Swallowed, savored

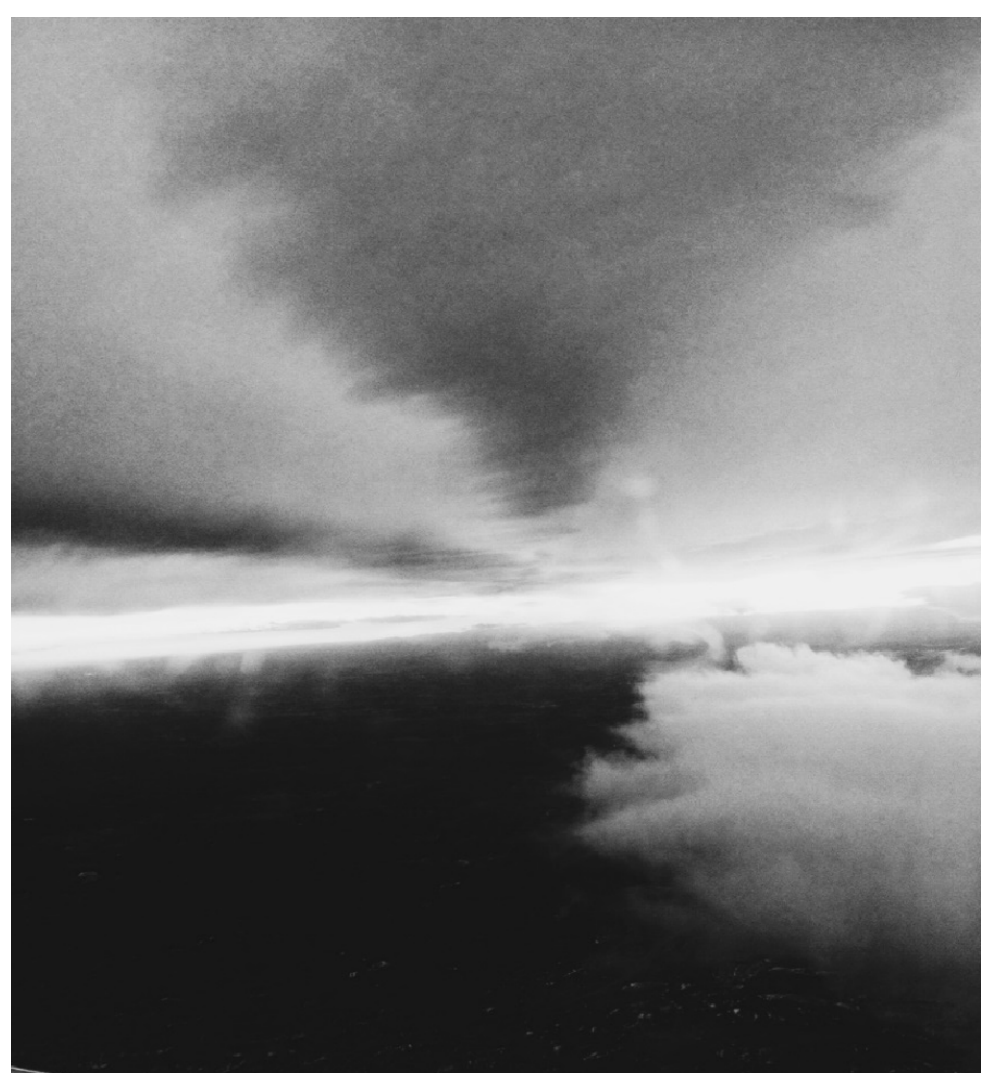

Settling smoothly

Summoning sleep. 
DOA

By Robert Johnson

Food for the dead

Dead on arrival, a

Fitting farewell

Comfort food

Cold comfort

Tell the kitchen

I want

Something

Nothing

Anything

Standard fare

A little care

Food that's

Hot

Cold

Flat

Rolled

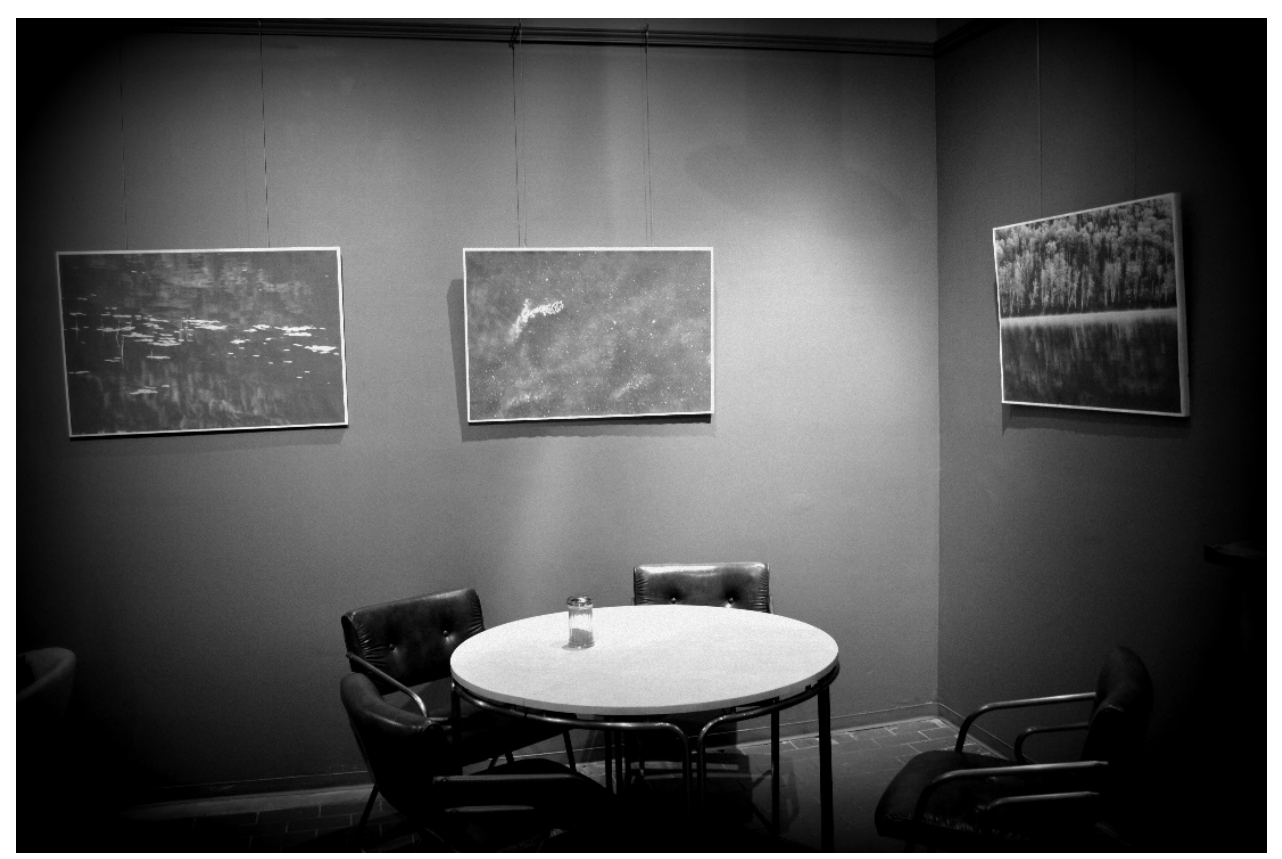

Food you can hold

On plate, in hand

Like a weapon

Or a white flag

Save some for tomorrow

One man said

He'd surrendered

Long ago

-

Dead

Dead on arrival. 


\section{Last Meal}

By Alexa Marie Kelly

We are made of bone

Pulled from the side

of a holy man

come undone

by woman and fruit

and promise.

Grease cloaks my fingers

like fog on a Sunday sky.

Cracking rib without grace,

I peel back layers of skin,

my teeth dusted black.

I am the cannibal

you want me to be

Spare my bones.

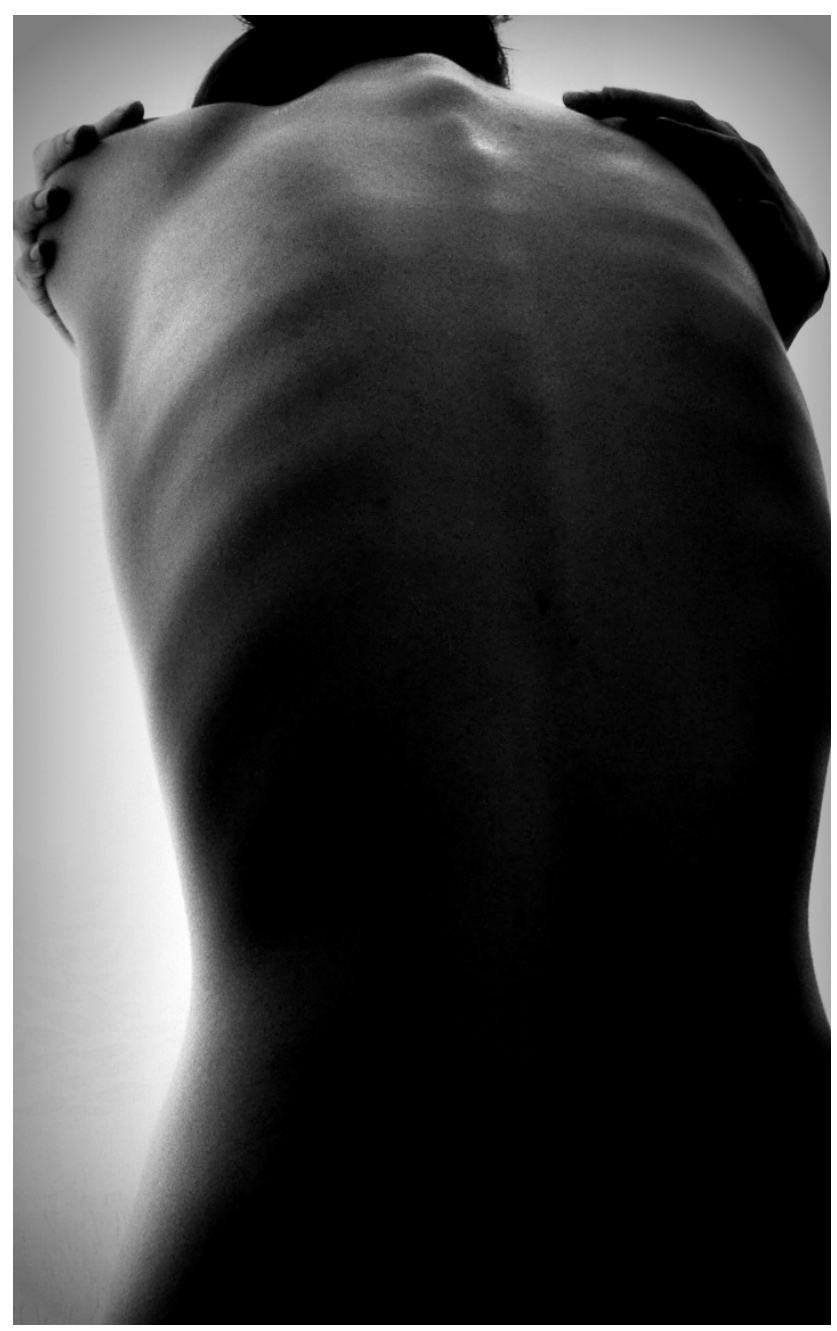




\section{A Single Olive}

By Sarah Bousquet

A single olive

Unpitted

Black against the

Bright white plate

The guard who brought it to her

Could not help

But ask

Why

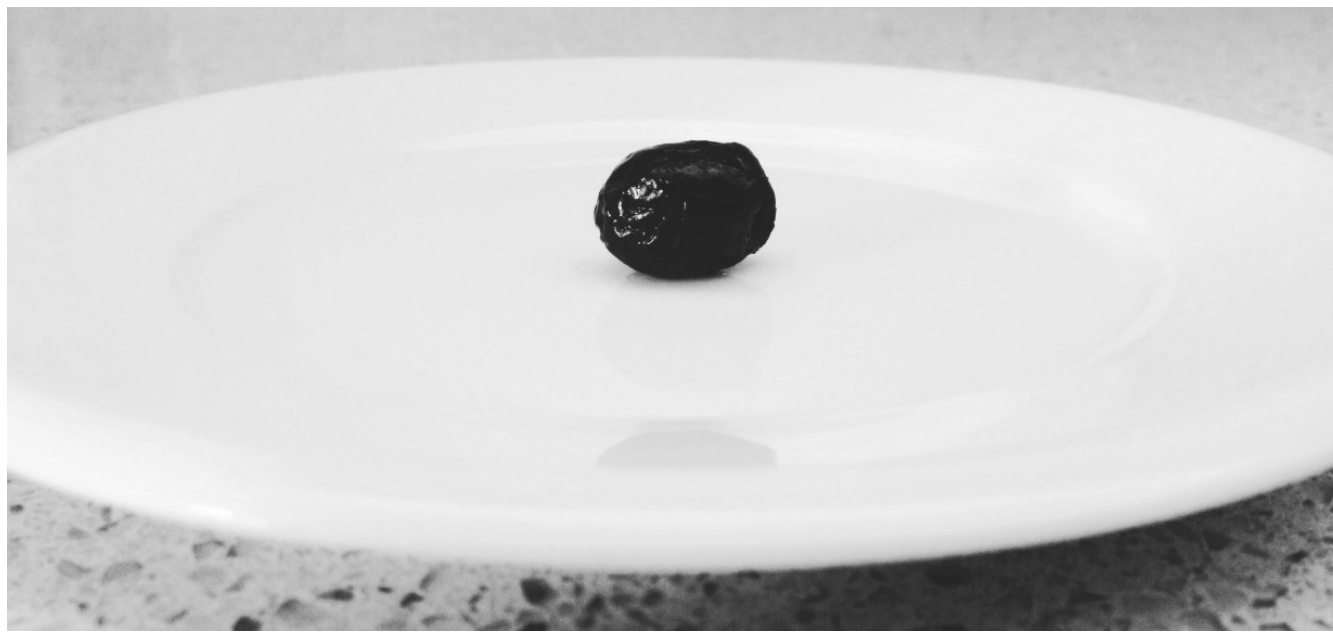

She smiled,

A pained smile

Corrupted

By the horrors of prison

She said

My mother used to say

If you ate

An unpitted olive,

An olive tree

Would grow

In your stomach

She said

Someone once told me

Olive trees

Mean peace

She said

Maybe, just maybe

If I eat this

An olive tree will grow

From my grave

And finally bring me peace. 


\section{Last Supper}

By Robert Johnson

A fried steak, diced into little squares, arrives at the death house neatly reassembled, like a puzzle, laid to rest in the center berth of a standard white styrofoam box bordered on one side by soggy, sagging fries, on the other by wilted greens, curled and brown, long past their salad days, like the man himself

who ordered this meal as the sad celebration

culmination, of a dreary, wasted life that it is even now slipping away as he ages before our eyes right there in his cell, called "the last night cell" in some prisons, arrives at the death house laid to rest in the center berth "the death cell" in this one.

Later, he will be cooked, in a manner of speaking, in the electric chair, but not diced or reassembled before he is boxed without frills in a plywood coffin, the mortuary's answer to the styrofoam box, and buried in the prison cemetery, home to the most common and indigestible waste of the prison system.

He eats alone with a plastic forkno knives for the condemned no dinner companions for the condemnedchewing carefully, kneeling by his bed, as if in genuflection before the raw power of the state, his meager meal placed carefully on the steel gray metal bed sitting precariously on the top sheet, drawn tight like a sail battened down for heavy weather.

We look at each other tentatively, almost furtively, lawyers, chaplains, even officers speaking in low tones, as if we are greasy, dirty, our mouths dry, our words directed toward the ground tongues swollen, sticking to our teeth 
our noses stinging from the scent of corruption, the bittersweet stink of fear in the air, in our hair, on our skin, in our clothes.

We are guests at a living wake where the dead live where the dead see look you in the eye and see nothing, see no one will save them see they are utterly alone.

The condemned man finishes his meal, says 'thank you' to the officers who fed him dinner, and later walks with them to his execution, on schedule, dead before the stroke of midnight. We go home, stomachs empty, hungry for sleep.

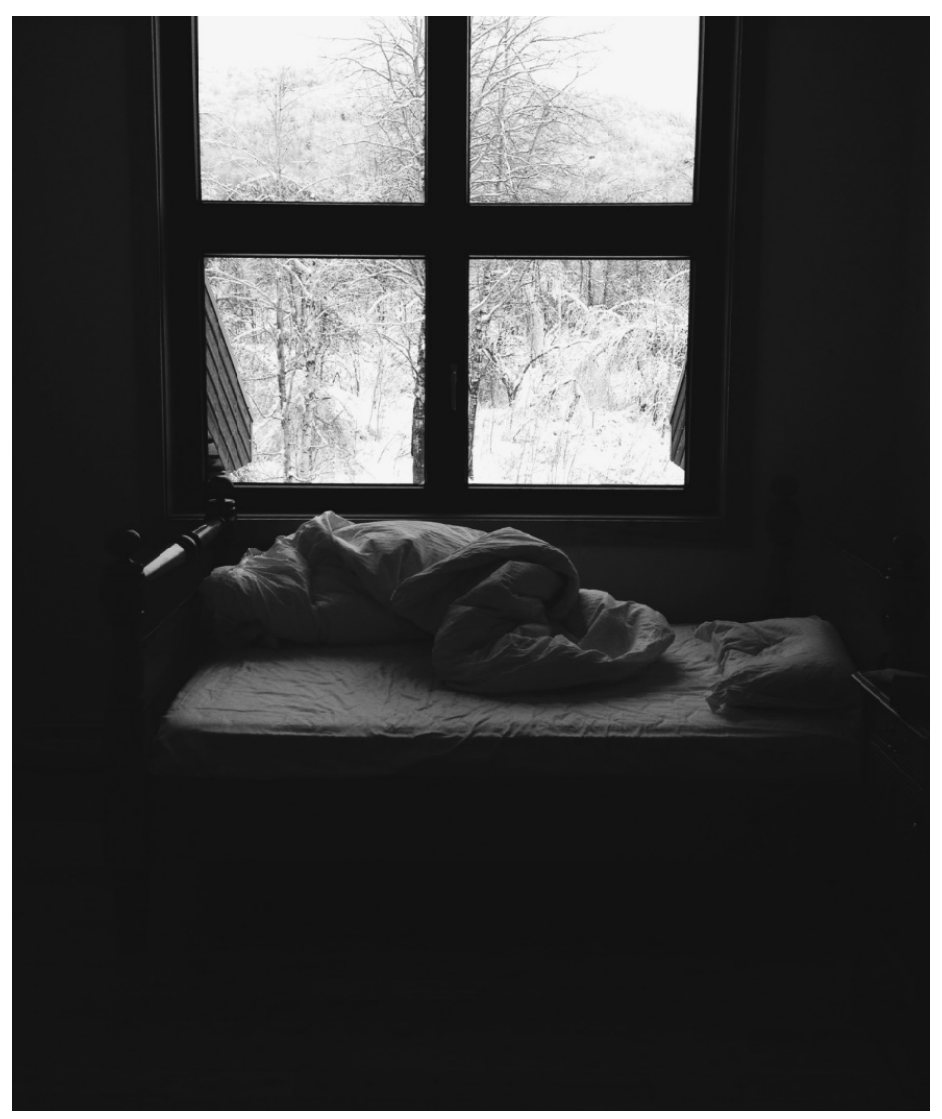




\section{Standards of Decency}

By Susan Nagelsen

The machine inches forward with

determination and precision, this macabre death scene created by institutions to satisfy the nation's need

for retribution.

The state's emissaries become voyeurs in a process determined to have victory over its enemy.

All movement is watched to ensure no harm comes to the intended victim.

There is irony in the reality that you can't kill yourself; the state is the first in line for that.

After all, can't have the spoils go to anyone other than the victor

A week before the poisons are injected, the business of dying is addressed. A small man, with half closed lids appears at the cell. "I'm here to measure you for your burial suit, and to help with paperwork." The state always has paperwork, even in dying.

Just another oddity in the march toward execution.

Each moment of the last day, scripted as tightly as a production of La Boehme that has been rehearsed to perfection so no unseemly emotions leak out from the players on the stage. It is a formulaic plan devised, to make it appear professional. 
Breakfast at 5:00, before anyone is awake, last visits scheduled during lockdown, when no one will have a chance to say goodbye, last meal, no more than forty dollars, when the clock strikes

ten.

Isolation brought him peace.

He had faith in the lessons learned this time around; next time he would do it better.

Ready to leave schoolhouse earth, he anticipated the freedom waiting for him on the other side.

"Set me free," said he.

And they did.

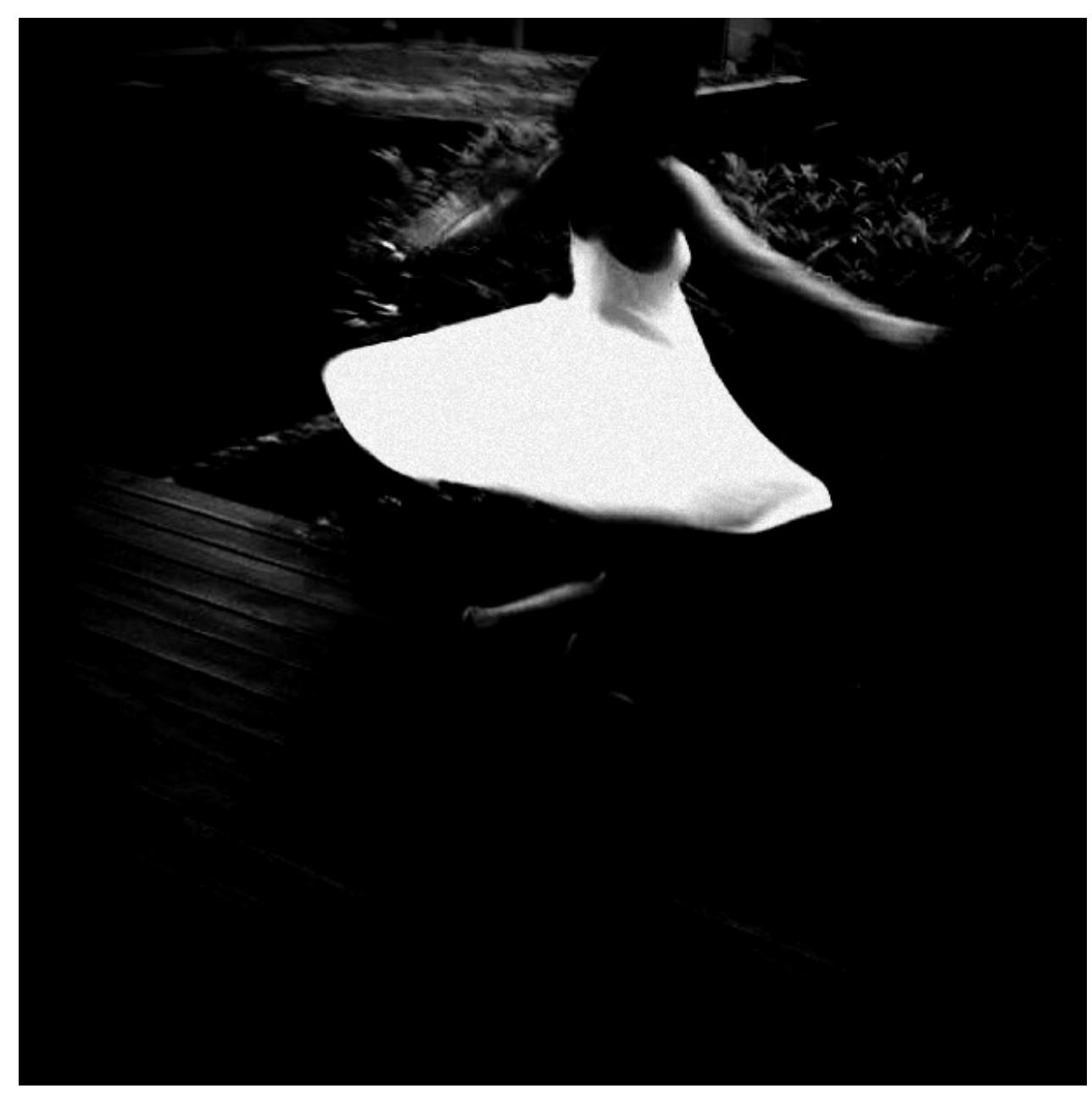




\section{Addendum}

\section{A Conversation with the Photographer:}

Robert Johnson (RJ): Tell me about your photo choices. Or, on a more basic level, explain why we use photographs to accompany the poems, which presumably speak for themselves.

Carla Mavaddat (CM): Photographs can complement poems because both mediums work with the most concise expression, whether in word or image, to capture the scene. The scenes evoked in the poems in our collection are all related to life on the threshold of execution, most notably as seen in the last meals and last reflections of the condemned

RJ: Let's take the first poem, Death House Serenade, which unfolds in "a delicious dialectic... summoning sleep", sleep that is to come in the execution chamber in the form of death.

CM: The poem describes a "sweet, soothing, sensual serenade" embodied in the meal and in the experience of the meal. The fusion of the clouds with the darkness in my photo evokes this mysterious sensuous feeling, which links itself to the feeling of fear of impending death, with the shadows of life slowly becoming darker and darker, as symbolized by the movement of the clouds into the receding sky. The black streak at the bottom left of the photo encompasses the fear before death we all would experience, and perhaps seek to escape through drifting through the experience, much as the subject in the poem drifts into what feels like a deep and, of course, final sleep.

RJ: Now, the poem DOA is more spare, more...

CM: Arid. Bare. For me, an empty table, solitary chairs and three lonely paintings serve up an image of serving up a meal for someone who is, as you say, DOA: dead on arrival. Life has ceased, the white table, like the white flag in the poem, is about the surrendering of life. There is no food. The dead don't eat.

RJ: A fair number of prisoners I'd describe as DOA don't eat what they order, for their last meals, as a matter of fact. Some who do, seem ravenous, eating with their hands, an image captured in Alexa Marie Kelly's “cannibal” in her poem, Last Meal.

CM: For me, these cannibals are both strong, eating what they want, and vulnerable, as captured in ribs, cracked ribs in the poem, ribs made visible in the photograph. The rib cage protects so much but is itself quite fragile. Perhaps we all say, at some point, "spare my bones" from the hazards of life and, here, from the death by killing that will come after the grease on the condemned man's hands is washed clean.

RJ: Sarah Bousquet's poem, A Single Olive, has a clean, spare, yet darkly uplifting quality to it.

CM: The single olive, black against a plain white plate in the photo, speaks most directly to the stark emptiness of a life that comes to an end in the death house, an emptiness belied or, better, given meaning by the peace and hope and life we associate with olive trees and which are so nicely 
articulated in this haunting poem. If the plate in the photograph is the grave, the olive stands above it, if not alive, at least intact, a miracle in its own right.

RJ: The Last Supper is a very personal poem for me, capturing, I hope, the scene and the feel of a last meal I observed as part of my research on the modern execution process. Your photo captures perfectly the feel of the experience, though I never would have thought to frame it as you did in the context of a bed below a window opening onto a winter scene that I see as cold and yet strikingly appealing.

CM: The hunger for sleep of which you write comes through most clearly to me. The bed is meant to beckon the viewer to rest, to drift off into the oblivion of sleep. The window opens up profound possibilities that unfold in the wonder that is sleep, from a clean, symmetrical view of the outside world, soon to be closed to the prisoner, to the "raw power of the state", to quote the poem, to frame and control reality, right up until the prisoner's demise, touching and saddening everyone that is a part of this deadly process. The winter scene in this photograph — cold, remote, replete with leafless brancheshas the bare and forbidding quality of death and, I hope, the cool repose we associate with sleep.

RJ: Susan Nagelsen's Standards of Decency takes the broadest view of the execution process in this collection, with resonances of Michel Foucault or Franz Kafka, both of whom offer elegant articulations of the disciplined machinery that carries the execution process along and which Nagelsen has captured in a style and cadence and content that build to a liberating crescendo.

CM: What I took away from the poem, and tried to embody in the photograph, is the sheer impersonality, isolation, and insidious, growing anxiety that come in the wake of executions. The inmate is waiting to be led to his death, it is scheduled and at a specific time; his fate is forced upon him. These are the hard, cold facts. The superposition of the playing of La Bohème with the declaration in the poem, "set me free", is meant to capture what must be an aching nostalgia among the condemned for the life they had or, more likely, might have had, if fate had been kinder.

RJ: There must be something better on the other side, the poem affirms, and that is something to celebrate.

CM: A reason to dance with abandon, one of the most primal celebrations we know of and see all around us.

RJ: Very human.

CM: Like eating and sleeping and dreaming...

RJ: And ultimately trying to make sense of life through our choices about how we deal with adversity, perhaps especially the adversity posed by a life violated by injustice. Those choices in the death house - the final desiderata - are examples of what you and I and our colleagues in this collection each see as a basic human right. 


\section{Author Contributions}

The authors of the poems comprising this collection are indicated in the text. All photographs were taken by Carla Mavaddat.

\section{Conflicts of Interest}

The authors declare no conflict of interests.

(C) 2014 by the authors; licensee MDPI, Basel, Switzerland. This article is an open access article distributed under the terms and conditions of the Creative Commons Attribution license (http://creativecommons.org/licenses/by/3.0/). 